\title{
References:
}

1. Hughes, B. L.; Zaki, J. The neuroscience of motivated cognition. Trends Cogn. Sci. 2015, 19, Pp. 62-64.

2. Sherwani K. A. A Cognitive Positive Discourse Analysis of English Motivational Speeches. International Journal of Advanced Science and Technology. Vol. 29, No. 9s, (2020), Pp. 4078-4091.

3. Mark Zuckerberg's Commencement address at Harvard. Mode of access: Mark Zuckerberg's speech as written for Harvard's Class of 2017 - Harvard Gazette

4. Steve Jobs' 2005 Stanford Commencement address. Mode of access: Text of Steve Jobs' Commencement address (2005) (stanford.edu)

DOI https://doi.org/10.30525/978-9934-26-073-5-1-48

\section{ОСОБЛИВОСТІ ПЕРЕКЛАДУ АНГЛІЙСЬКИХ ФРАЗЕОЛОГІЧНИХ ОДИНИЦЬ ІЗ АНІМАЛІСТИЧНИМ КОМПОНЕНТОМ УКРАЇНСЬКОЮ МОВОЮ}

\author{
Василенко О. М. \\ кандидат психологічних наук, \\ дочент кафедри іноземних мов за професійним спрямуванням \\ Національного педагогічного університету імені М. П. Драгоманова \\ м. Київ, Україна
}

Словниковий склад мови відкритий і постійно змінюється, зокрема іiі одиниці набувають нових значень. У правильності і повноті передачі інформації полягає власне відмінність перекладу від переказу чи скороченого викладу, від будь-якого виду так званих адаптацій. Тому зрозуміло, що можливість правильно передати позначення речей, про які йдеться в оригіналі, і образів, які з ними пов'язані, передбачає наявність певних знань про дійсність, зображену в тексті оригіналу (незалежно від того, чи ці знання надбані шляхом прямого знайомства 3 нею, чи взяті 3 книг або інших джерел). Професор І. Корунець вважає, що засоби перекладу залежать від структури, значення та мовного рівня змістових одиниць. Оскільки переклад є лінгвістичним предметом і він будується на значенні мовних одиниць, то перекладач орієнтується у рівнях цих мовних одиниць [1, с. 179].

У літературі існує багато пропозицій оцінки перекладних еквівалентів. Найбільш переконливою класифікацією еквівалентів в 184 
різних мовах $є$ система п'яти ступенів (повні еквіваленти, часткові еквіваленти, відносні еквіваленти, фразеологічні аналоги, безеквівалентні фразеологізми), сформована О.Селівановою на досвіді багатьох сучасних і більш ранніх класифікацій [2, с. 27-28].

Було досліджено 200 фразеологічних одиниць (ФО) англійської мови, що містять анімалістичний компонент, та їхні українські відповідники. За допомогою фразеологічних словників англійської та української мов до кожного 3 аналізованих ФО із анімалістичним компонентом було добрано один або більше відповідників або встановлено відсутність еквівалента.

1. Повні еквіваленти мають однакову структуру, подібну основу, переносне значення і функціонально-стилістичне забарвлення. Англійських анімалістичних фразеологізмів, які мають, серед інших, повний еквівалент, було знайдено 52 одиниці (26 \%) від усіх проаналізованих ФО із такими компонентами (lost sheep $\rightarrow$ заблудла вівия; a rare bird $\rightarrow$ piдкісний nтаx; barking dogs seldom bite $\rightarrow$ собака гавкає, та не кусає; а dark horse $\rightarrow$ темна конячка; don't change horses in midstream $\rightarrow$ коней на переправі не міняють; the lion's share $\rightarrow$ левова частка та інші). 352 ФО, що мають повні еквіваленти, найбільше виявилося із компонентом horse - кінь.

2. Часткові еквіваленти - таке ж значення i внутрішню форму $\mathrm{i}$ відрізняються або за структурою, набору синонімічних компонентів, сполучуваності, кількості компонентів, ступеня вживання, або за іншою ознакою, що випливає 3 граматичної структури мови перекладу. Англійських фразеологізмів-анімалізмів, які мають частковий еквівалент як найбільший відповідник, було знайдено 22 одиниці (11 \%) від усіх проаналізованих ФО (like a moth (that flies) round a light $\rightarrow$ немов метелик до вогню; don't count уоur chickens $\rightarrow$ курчат восени рахують; water off a duck's back $\rightarrow$ як з гуски вода; the brain of a pigeon $\rightarrow$ курячі мізки; to cherish a snake in опе's bosom $\rightarrow$ пригріти змію на грудях та інші). Наприклад, ФО the brain of a pigeon співпадає за семантикою та образністю із українським фразеологізмом курячі мізки. Він також містить анімалізм, що належить до групи «птах». Проте, в українському фразеологізмі використовується назва іншого класу птахів, тому цей еквівалент можна вважати тільки частковим.

3. Відносні еквіваленти при тому ж значенні частково замінюють образність, але залишаються зіставними. Англійських фразеологізміванімалізмів, які мають відносний еквівалент як найбільший відповідник, було знайдено 19 одиниць (9,5%) від усіх проаналізованих ФО (a bird in the hand is worth two in the bush $\rightarrow$ краще синиця в руках, ніж журавель $y$ 
небi; as black as a crow $\rightarrow$ чорний, як воронове крило; like a duck to water $\rightarrow$ як риба у воді; packed like sardines $\rightarrow$ як оселедиі в бочиі; to milk the bull $\rightarrow$ чекати від козла молока; to work like a racing dog $\rightarrow$ праџювати, як віл). Як бачимо 3 наведених прикладів, більшість анімалістичних компонентів було змінено при перекладі. Інколи зміна відбувається тільки у класі, при збереженні одного і того самого виду: to milk the ram $\rightarrow$ чекати від козла молока; інколи має місце зміна вида: dumb as an oyster $\rightarrow$ німий, як риба; в деяких випадках відбувається заміна гіпероніма гіпонімом: a knowing old bird $\rightarrow$ стріляний горобещь.

В деяких ФО анімалізм залишається таким самим, проте їх не можна віднести до часткових еквівалентів через значну зміну образності або експресії, що позначається на семантиці. Наприклад, у ФО to ride a hobby horse to death в якості відносного еквівалента було обрано сісти на свого улюбленого коника. Тут співпадає анімалістичний компонент, проте через використання зменшувального суфікса в українському варіанті змінюється експресивність та семантика. Крім того, український еквівалент опускає фразу to death, через що передає більш широке значення ФО, ніж англійський варіант.

4. Фразеологічні аналоги мають різну образність або структуру, але загальне значення і стилістику. Англійських фразеологізмів з анімалістичним компонентом, які мають фразеологічний аналог як найбільший відповідник, було знайдено 35 одиниць (17,5 \%) від усіх проаналізованих ФО (to kill two birds with one stone $\rightarrow$ убити відразу двох зайців; a little bird told те $\rightarrow$ земля чутками повниться; every bird likes his own nest $\rightarrow$ усякий кулик до свого болота звик; act the ass $\rightarrow$ клеїти дурня; not stand a cat in hell's chance $\rightarrow$ не мати жодного шансу; по spring chicken $\rightarrow$ не першої молодості та інші).

Наприклад, фразеологічним аналогом для ФО eat like a horse $\epsilon$ український фразеологізм їсти, як свиня. Тут частково співпадає семантика, оскільки фразеологізм «їсти, як свиня» актуалізує не тільки значення багато їсти, але й значення неохайно їсти. Це друге значення в англійському фразеологізмі не реалізовано. Крім того, вживання анімалізму свиня повідомляє додаткову негативну конотацію українському варіанту, що змінює стилістику.

Англійський фразеологізм be on the high horse співпадає за анімалістичним компонентом з українським бути на коні, проте має вужчу семантику, яка повідомляється вживанням лексеми high - високий. Тому англійська ФО вживається виключно в значенні величатися, а українська має два значення - і величатися, і бути в змозі щось зробити. Отже, ці ФО є фразеологічними аналогами. 
5. Безеквівалентні фразеологізми є ідіомами, властивими лише одній мові. Було знайдено 72 одиниці (36 \%) фразеологізмів-анімалізмів, що не містять еквівалента в українській мові. Деякі фразеологізми можуть перекладатися калькою, але для перекладу більшості з них доводиться вдаватися до описового перекладу.

Безеквівалентних фразеологізмів, які можна перекладати калькою було виявлено 11 (5,5 \%). Переклад калькою доцільний тоді, коли ФО повністю розкриває свою семантику через наявні в ньому компоненти i не потребує додаткових пояснень, як, наприклад, у випадках dead the $\boldsymbol{d o g}$, the rabies is gone $\rightarrow$ померла собака, закінчилася $\check{u}$ лють; the great fish eat the small $\rightarrow$ велика риба з'їдає малу. Ці кальки стилістично відповідають оригіналу, а також узгоджуються із граматичними нормами української мови.

Безеквівалентних фразеологізмів, які доцільно перекладати описовим перекладом, було знайдено 61 одиниць (30,5 \%). Вони можуть бути змінені в залежності від перекладацьких завдань, стилю та жанру літератури, що перекладається тощо. Описовий переклад безеквівалентних ФО доцільний тоді, коли переклад калькою чи дослівний переклад не можуть розкрити значення фразеологізмів. Наприклад, переклад calf love калькою теляча любов нагадуватиме український фразеологізм телячі ніжності. Але цей український варіант має семантику недоречні або незграбні ніжності, яка зовсім не відповідає значенню англійської ФО перше підліткове кохання - роман. Переклад калькою ФО pigs in clover може викликати недоречні асоціації із крилатою фразою свиня nid дубом, яка має значення невдячна людина, тоді як англійський оригінал має значення вискочка.

Отже, серед аналізованих анімалістичних ФО англійської мови найбільше виявилося таких, які доцільно перекладати описово (30,5 \%). В той же час, понад чверті (26 \%) мають повні еквіваленти в українській мові, які повністю збігаються за семантикою (принаймні, в одному із фразеологічних значень). Середню частотність продемонстрували фразеологічні аналоги. 17,5 \% англійських анімалістичних фразеологізмів мають в українській мові аналоги з іншою образністю або такі, що суттєво відрізняються за структурою, можуть мати інший анімалістичний компонент або взагалі не мати і збігатися тільки за семантикою повністю або в одному із значень (якщо ФО багатозначна). Майже однакову кількість виявлено часткових еквівалентів та відносних еквівалентів (11 \% та 9,5\% відповідно). Найменше виявилося безеквівалентних ФО, які можна відтворити калькою (5,5 \%). 


\title{
Література:
}

1. Корунець I. Теорія і практика перекладу (аспектний переклад). Вінниця: Нова Книга, 2011. 448 с.

2. Селіванова О. Нариси з української фразеології (психокогнітивний та етнокультурний аспекти). Черкаси: Брама, 2014. 276 с.

3. Білоноженко В. Гнатюк І. Словник фразеологізмів української мови. Режим доступу: https://archive.org/details/slov557

DOI https://doi.org/10.30525/978-9934-26-073-5-1-49

\section{ВЗАСМОЗВ'ЯЗОК КОНЦЕПТІВ ЕРIDEMIC, РАNDEMIC TA CORONAVIRUS У СУЧАСНИХ РЕАЛІЯХ}

\author{
Гахарія К. В. \\ аспірантка кафедри англійської філології \\ Запорізького національного університету \\ м. Запоріжжя, Украӥна
}

Наразі лінгвістична наука прагне досліджувати внутрішні когнітивні процеси особистості, їхні особливості, передумови виникнення тих або інших явищ у нашій свідомості, а також вплив цих чинників на мотивацію дій і людську поведінку. Саме через це наукові розвідки у сфері когнітивної лінгвістики, зокрема, ті, що розкривають досі не відомі факти про особливості співвідношення людської свідомості та пізнання через засоби мови, мають високий пріоритет у мовознавчих студіях. Одним із прикладів таких актуальних сфер наукового пошуку є вивчення концептів, їх функціонування та впливу на суспільство.

Пандемія коронавірусу внесла свої корективи у порядок денний людства. Так, сучасний науковий дискурс активно поповнюється роботами, пов'язаними із медициною, хворобами та способами захисту здоров'я. Тема COVID-19 проникла в усі галузі знань; не стали виключенням і мовознавчі розвідки. У них чимало уваги присвячено неологізмам, утвореним у зв'язку 3 пандемією; формуванню концепту CORONAVIRUS та його проявам у мас-медійному дискурсі; вивченню впливу функціонування у масовій свідомості цього концепту на поведінку та психіку людей тощо. Утім, на наш погляд, залишаючи поза увагою споріднені концепти EPIDEMIC, PANDEMIC та їхній взаємозв'язок із концептом CORONAVIRUS, лінгвісти оминають значний пласт 